University of Nebraska - Lincoln

DigitalCommons@University of Nebraska - Lincoln

Management Department Faculty Publications

Management Department

2013

\title{
The dark side of personality at work
}

Seth M. Spain

Binghamton University, sspain@binghamton.edu

Peter D. Harms

University of Nebraska - Lincoln, pharms@gmail.com

James M. Lebreton

Pennsylvania State University, james.lebreton@psu.edu

Follow this and additional works at: https://digitalcommons.unl.edu/managementfacpub

Spain, Seth M.; Harms, Peter D.; and Lebreton, James M., "The dark side of personality at work" (2013). Management Department Faculty Publications. 99.

https://digitalcommons.unl.edu/managementfacpub/99

This Article is brought to you for free and open access by the Management Department at DigitalCommons@University of Nebraska - Lincoln. It has been accepted for inclusion in Management Department Faculty Publications by an authorized administrator of DigitalCommons@University of Nebraska - Lincoln. 


\title{
The dark side of personality at work
}

\author{
Seth M. Spain, ${ }^{1}$ Peter Harms, ${ }^{2}$ and James M. Lebreton ${ }^{3}$ \\ 1. School of Management, Binghamton University, Vestal, NY USA. \\ 2. Department of Management, College of Business Administration, \\ University of Nebraska-Lincoln, Lincoln, NE, USA. \\ 3. Department of Psychology, Pennsylvania State University, University Park, PA, USA. \\ Corresponding author - Seth M. Spain, School of Management, Binghamton University, \\ Vestal, NY, USA; email sspain@binghamton.edu
}

\begin{abstract}
Although there has been increasing interest in dark personality traits in the organizational sciences, these characteristics remain relatively understudied and somewhat misunderstood. The present manuscript aims to clarify some of the issues surrounding dark personality traits by discussing the history of dark personality traits, how they relate to normal personality traits, their relative importance as determinants of organizational outcomes, and measurement issues surrounding the assessment of these characteristics. We will then discuss potential future directions for research investigating the causes and consequences of these traits as well as providing guidance on the implementation of dark personality assessment in the workplace for selection and training.
\end{abstract}

Keywords: dark side of personality, Dark Triad, subclinical personality traits

$\mathrm{I}_{z}^{\mathrm{n}}$ $\mathrm{n}$ the wake of public scandals during this century, there has been increasing attention within the organizational sciences toward negative aspects of organizational life. These areas are often demarcated by the evocative adjectives applied to them-deviant, aberrant, and toxic. Organizational researchers have shown an upsurge of interest in the dark side of work experiences. Consequently, there has been increasing interest among organizational scholars in the "dark side" of personality. Although normal personality characteristics can be good predictors of workplace outcomes, notably aspects of job performance (Barrick \& Mount, 1991), but the extant research may be limited by over-reliance on the dominant paradigm in trait psychology: the five-factor model or Big Five. A number of scholars have noted that other individual differences, such as motives, interests, and goals, are not easily subsumed by the five factors (James \& LeBreton, 2010; Roberts, Harms, Smith, Wood, \& Webb, 2006a); consequently, there have been increasing calls for research in the organizational sciences that go beyond the five factors (e.g., Judge, Piccolo, \& Kosalka, 2009). The current article sets out to review research relevant to understanding the dark side of personality at work, which we contrast with the aforementioned work on the bright side of personality.

More specifically, this paper seeks to justify why the dark side of personality is one meaningful approach to going beyond the Big Five. We review evidence that the constructs of the dark side are useful in their own right and incrementally above normal-range personality characteristics. We first attempt to create a tighter definition of what is meant by the dark side of personality, which we revisit later in the manuscript in an attempt to set an initial taxonomy of dark side characteristics. We then review the literature on the dark side, focusing on its relationships to the most common bright side taxonomies in organizational research (i.e., the five-factor model and the HEXACO model), and we explore the utility of dark traits in predicting various organizational outcomes. We also address the measurement of dark side traits, introduce a rudimentary taxonomy of dark side characteristics, and highlight areas for future research.

\section{The Meaning of Dark Personality}

The dark side of personality has attracted increasing popular attention. For example, Babiak and Hare (2006) discussed psychopaths in a variety of work contexts in a popular book, Snakes in Suits: When Psy- 
chopaths Go to Work. Nassir Ghaemi's (2011) A First-rate Madness: Uncovering the Links between Leadership and Mental Illness proposes that the most effective leaders in times of crisis are those who have suffered from mental illness or personality defects. Yet despite the rise of interest in dark traits among the general public and personality researchers, neither of the major handbooks covering personality theory and research devotes even a chapter to the subject (Chamorro-Premuzic, von Stumm, \& Furnham, 2011; John, Robins, \& Pervin, 2008).

\section{Absence of dark personality in psycholexical research}

The term dark has strong connotations, and the dark side of personality does not seem to be well described within the five-factor framework. For instance, Tellegen (1993) aimed criticism at the Big Five as deficient as the lists of adjectives it is based on eliminated evaluative terms (such as "evil" or "dangerous"; Allport \& Odbert, 1936). A great deal of the pre-history of the Big Five rests on factor analytic work emerging from this lexicon (Goldberg, 1981) and the elimination of evaluative terms is one reason why personality researchers have not included dark personality characteristics in general taxonomies, such as the Big Five. When such evaluative terms were added back into lexical studies, two new factors emerged, Positive Valence and Negative Valence (the "Big 7" model; Waller \& Zavala, 1993; note: these traits should not be confused with Positive and Negative Emotionality). The presence of these new factors indicates that terms considered dark, such as "evil," are not only potentially important domains of personality but are also not simply extreme indicators of Big Five dimensions (i.e., Negative Valence is not "very disagreeable").

\section{Dark Personality: What Is Known}

The majority of modern research involving dark personality has focused either on three traits commonly referred to as the Dark Triad-Machiavellianism, Narcissism, and Psychopathy (Paulhus \& Williams, 2002) - or on models of dark traits based on DSM-IV Axis II disorders (Hogan \& Hogan, 2001; 2009). Paulhus's approach for identifying dark traits is focused on pathologies characterized by motives to elevate the self and harm others (Paulhus \& Williams, 2002), whereas Hogans' approach focuses on the dark side as negative characteristics that emerge when individuals let down their guard (Hogan \& Hogan, 2001).

\section{The Dark Triad}

Machiavellianism is a manipulative personality, derived from questioning individuals on how much they agree with statements derived from Machiavelli's writings (Christie \& Geis, 1970). Individuals high in Machiavellianism are called high-Machs, and they are characterized by a lack of empathy, low affect, possessing an unconventional view of morality - a willingness to manipulate, lie to, and exploit others - and focus exclusively on their own goals/agenda, not those of others' (Christie \& Geis, 1970; Wu \& LeBreton, 2011). High-Machs are exceedingly willing to manipulate others and take a certain pleasure in successfully deceiving others, but they do not necessarily have superior ability to do so (Jones \& Paulhus, 2009).

Narcissism emerged from Raskin and Hall's (1979) attempts to develop a subclinical version of narcissistic personality disorder (PD). Narcissism therefore has facets from its clinical variant-grandiosity, entitlement, dominance, and superiority. Narcissists have tendencies to engage in self-enhancement (Raskin, Novacek, \& Hogan, 1991) and can therefore appear charming or pleasant in the short term. In the long term, however, narcissists have difficulty maintaining successful interpersonal relationships, lacking trust and care for others, and sometimes feeling disdain for them (Morf \& Rhodewalt, 2001). Narcissism is probably the dark side trait that has received the most research attention in the organizational sciences (see Campbell, Hoffman, Campbell, \& Marchiso, 2011, for an overview). 
Psychopathy has been described as impulsivity and thrill seeking combined with low empathy and anxiety (Babiak \& Hare, 2006; Hare, 1985; Skeem, Polaschek, Patrick, \& Lilienfeld, 2011). Psychopaths are characterized as antagonistic and have a belief in their own superiority and a tendency toward self-promotion (LeBreton, Binning, \& Adorno, 2006; Lynam \& Widiger, 2007). Psychopaths have a unique affective experience, such that it has been suggested that the definitive marker of psychopathy is a lack of the self-conscious emotion guilt and an absence of conscience (Hare, 1999). Furthermore, psychopaths do not experience anxiety and fear to the extent that normal people do and are also less prone to experience embarrassment (Cleckley, 1976; Hare, 1999). Consequently, they often fail to learn from punishment for misdeeds. Psychopaths are also impulsive and seek immediate gratification of their needs (Cleckley, 1976; Hare, 1999).

Paulhus's approach to subclinical traits was a major influence on the study of normal personality in aberrant or dysfunctional operation. His use of the "Dark Triad" nomenclature is one reason that researchers refer to the study of subclinical traits as the dark side, in contrast to the bright side of the Big Five. Dark personality is the middle ground between normal personality and clinical-level pathology. Sadly, the vast majority of research on these traits utilizes either student (for the study of Narcissism and Machiavellianism) or incarcerated populations (for the study of Psychopathy). Consequently, although a great deal is known about the nature of these traits, very little has crossed over into workplace research.

\section{Axis II approaches to dark personality}

More recently, interest has begun to coalesce around subclinical versions of the DSM-IV Axis II PDs (American Psychological Association, 1994), often measured with the Hogan Development Survey (HDS; Hogan \& Hogan, 2001). The HDS assesses 11 subclinical traits, which may be expected to lead to potential short-term advantages, but could be associated with problems over the long term (Hogan, 2007; Hogan \& Hogan, 2009; Hogan \& Kaiser, 2005). These traits, and their clinical counterparts, are further detailed in Table 1, which also provides our estimation of where the Dark Triad should be located, with Machiavellianism aligned with Paranoid, the best place we can determine for it on the basis of its association with cynicism and distrust. The HDS uses euphemistic naming in place of the rather more negatively termed DSM-IV Axis II disorders. Consider Skeptical, which roughly corresponds to Paranoid PD. Individuals scoring high on Skeptical are described as having chips on their shoulders and are cynical, distrustful, easy to anger, and suspicious of others' motives. Individuals low on Skeptical are perfectly capable of trusting others. In other words, high-Skeptical individuals display behavior patterns that are similar to Paranoids but not at levels so debilitating to necessitate clinical intervention (for a more detailed description of the clinical vs. subclinical distinction, the reader is directed to LeBreton, Binning \& Adorno, 2006; Wu \& LeBreton, 2011).

Although these subclinical characteristics may be problematic in some settings (Wu \& LeBreton, 2011), they may not always hinder day-to-day functioning (Hogan \& Hogan, 2001). Sometimes, these traits may prove beneficial, at least under very specific circumstances (e.g., Harms, Spain, \& Hannah, 2011a). These traits have been found to have important consequences for performance (Benson \& Campbell, 2007; Harms, Spain, Hannah, Hogan, \& Foster, 2011b; O'Boyle, Forsyth, Banks, \& McDaniel, 2012) and leader development (Harms, Spain \& Hannah, 2011a). Individuals with these traits are significantly more likely to have trouble with their supervisors, so their behavior is clearly important to organizational researchers and practicing managers.

\section{Dark Personality in Relation to Other Models of Personality}

\section{Dark personality and normal-range personality}

There is overlap between normal-range personality and clinical-level PDs: traits in both domains share latent dimensions (Markon, Krueger, \& Watson, 2005; Walton, Roberts, Krueger, Blonigen, \& Hicks, 2008; Widiger \& Trull, 2006), and efforts have been made to use the five-factor model (at the facet level) to de- 
Table 1. Subclinical dimensions of the HDS.

\begin{tabular}{|c|c|c|c|c|}
\hline $\begin{array}{l}\text { Subclinical } \\
\text { trait }\end{array}$ & $\begin{array}{l}\text { DSM-IV } \\
\text { Construct }\end{array}$ & $\begin{array}{l}\text { Dark Triad } \\
\text { Construct }\end{array}$ & Description of high scorers & DSM-IV descriptions \\
\hline Excitable & Borderline & & $\begin{array}{l}\text { Moody and inconsistent concerns; } \\
\text { being enthusiastic about persons, } \\
\text { ideas, and projects and then } \\
\text { becoming disappointed in them }\end{array}$ & $\begin{array}{l}\text { Inappropriate anger; unstable } \\
\text { and intense relationships }\end{array}$ \\
\hline Skeptical & Paranoid & Machiavellianism? & $\begin{array}{l}\text { Cynical, distrustful, overly sensitive } \\
\text { to criticism, and skeptical of others' } \\
\text { true intentions }\end{array}$ & $\begin{array}{l}\text { Distrustful and suspicious } \\
\text { of others; motives of others } \\
\text { are interpreted negatively }\end{array}$ \\
\hline Cautious & Avoidant & & $\begin{array}{l}\text { Resistant to change and reluctant } \\
\text { to take even reasonable chances for } \\
\text { fear of being evaluated negatively }\end{array}$ & $\begin{array}{l}\text { Social inhibition; feelings of } \\
\text { inadequacy; hypersensitivity } \\
\text { to criticism }\end{array}$ \\
\hline Reserved & Schizoid & & $\begin{array}{l}\text { Socially withdrawn and lacking } \\
\text { interest in or awareness of the } \\
\text { feelings of others }\end{array}$ & $\begin{array}{l}\text { Emotional coldness and } \\
\text { detachment from relation- } \\
\text { ships; indifferent to criticism }\end{array}$ \\
\hline Leisurely & $\begin{array}{l}\text { Passive } \\
\text {-aggressive }\end{array}$ & & $\begin{array}{l}\text { Autonomous, indifferent to the } \\
\text { requests of others, and often } \\
\text { irritable when others persist }\end{array}$ & $\begin{array}{l}\text { Passive resistance to } \\
\text { performance expectations; } \\
\text { irritable when asked to do } \\
\text { unwanted tasks }\end{array}$ \\
\hline Bold & Narcissistic & Narcissism & $\begin{array}{l}\text { Unusually self-confident, unwilling } \\
\text { to admit mistakes or listen to advice, } \\
\text { and unable to learn from experience }\end{array}$ & $\begin{array}{l}\text { Grandiose sense of self-impor } \\
\text { tance and entitlement; arro- } \\
\text { gant behaviors and attitudes }\end{array}$ \\
\hline Mischievous & Antisocial & Psychopathy & $\begin{array}{l}\text { Enjoys taking risks and testing the } \\
\text { limits }\end{array}$ & $\begin{array}{l}\text { Disregard for the truth; } \\
\text { impulsive; failure to } \\
\text { conform to social norms }\end{array}$ \\
\hline Colorful & Histrionic & & $\begin{array}{l}\text { Expressive, dramatic, and desires } \\
\text { to be noticed }\end{array}$ & $\begin{array}{l}\text { Excessive emotionality } \\
\text { and attention seeking }\end{array}$ \\
\hline Imaginative & Schizotypal & & $\begin{array}{l}\text { Acts and thinks in creative and } \\
\text { unusual ways }\end{array}$ & $\begin{array}{l}\text { Odd beliefs and thinking; } \\
\text { behavior or speech that is } \\
\text { eccentric or peculiar }\end{array}$ \\
\hline Diligent & $\begin{array}{l}\text { Obsessive } \\
\text {-compulsive }\end{array}$ & & $\begin{array}{l}\text { Careful, precise, and critical of } \\
\text { the performance of others }\end{array}$ & $\begin{array}{l}\text { Preoccupations with orderliness, } \\
\text { rules, and control; inflexible }\end{array}$ \\
\hline Dutiful & Dependent & & $\begin{array}{l}\text { Eager to please, reliant on others } \\
\text { for support, and reluctant to take } \\
\text { independent action }\end{array}$ & $\begin{array}{l}\text { Difficulty making everyday } \\
\text { decisions without excessive } \\
\text { advice and reassurance; unwilling } \\
\text { to express disagreement }\end{array}$ \\
\hline
\end{tabular}

Descriptions taken from HDS manual (Hogan \& Hogan, 2009). The DSM-IV Construct is the clinical-level psychopathology associated with a given HDS dimension. The Dark Triad is the closest approximating characteristic in the Dark Triad taxonomy. HDS = Hogan Development Survey.

scribe personality dysfunction (cf. Lynam \& Widiger, 2007; Miller, Bagby, Pilkonis, Reynolds, \& Lynam, 2005). We next review the overlap between dark and normal personality models.

\section{The Dark Triad and the Big Five}

As noted earlier, the Big Five model of personality was derived from psycholexical research aimed at uncovering the most important dimensions of personality. Five primary dimensions were uncovered: Extraversion, Neuroticism (or Emotional Stability), Agreeableness, Conscientiousness, and Openness to Experience. Each of the Dark Triad traits is negatively associated with Big Five agreeableness (cf. Wu \& LeBreton, 2011), largely because of their socially noxious nature (Paulhus \& Williams, 2002). However, each of the traits also has a unique pattern of relationships with the remaining Big Five traits. For exam- 
ple, both Machiavellianism and Psychopathy are negatively related to conscientiousness whereas Narcissism and Psychopathy are positively associated with Openness and Extraversion. Further, Narcissism and Machiavellianism are positively associated with Neuroticism, but Psychopathy is negatively related with it (Wu \& LeBreton, 2011).

Dark personality and the HEXACO model

The HEXACO model is based on lexical analyses of a number of non-English languages that have uncovered a sixth replicable dimension that has been termed "Honesty-Humility" (Ashton et al., 2004). The Honesty-Humility dimension consists of content related to feelings of entitlement, willingness to deceive to others, and greed (Ashton \& Lee, 2009). This dimension is substantially related to each of the Dark Triad traits (Lee \& Ashton, 2005). Honesty-Humility might be a generalized dark personality trait, such as Negative Valence. This notion is supported by evidence pointing to Honesty-Humility relating to workplace deviance above and beyond the effects of the Big Five (Lee, Ashton, \& de Vries, 2005; Zettler \& Hilbig, 2010).

Dark personality and Hogan 7-factor model

The Hogan Personality Inventory (HPI) represents another variant of the Big Five model of personality where two traits (Extraversion and Openness to Experience) are split to reflect application in work settings (Hogan \& Hogan, 2009). Consequently, the HPI consists of seven primary scales: Adjustment, Ambition, Sociability, Interpersonal Sensitivity, Prudence, Inquisitive, and Learning Approach. The HPI and HDS are intended to be complementary personality inventories assessing both normal and dark personality traits but considerable overlap between some scales. For example, HDS Excitable is correlated -.71 with HPI Adjustment, HDS Caution is correlated -.68 with HPI Ambition, and HDS Colorful is correlated .61 with HPI Sociability. Although there is no great deal of published research using both the HPI and the HDS, Harms, Spain, Hannah, et al. (2011) have found substantial incremental validity for using the HDS scales to predict leadership effectiveness outcomes above and beyond the HPI.

\section{Dark personality and the Big 7}

Positive Valence and Negative Valence reflect maladaptive self-evaluative processes and are therefore implicated in narcissism, borderline personality, and avoidant personality (Benet-Martinez \& Waller, 2002). Positive Valence is anchored by terms such as excellent and outstanding versus ordinary, which could suggest a grandiose sense of self (Hough \& Ones, 2001), potentially indicating narcissistic and histrionic PDs (Simms, Yufik, \& Gros, 2010). Negative Valence is anchored by terms such as bad and evil versus decent, suggesting a desire to display a wicked self-image (Hough \& Ones, 2001): the DSM-IV (APA, 1994) indicates that individuals suffering Borderline PD "usually have a self-image that is based on being bad or evil" (p. 707). Negative Valence non-specifically predicts most PDs (Durrett \& Trull, 2005; Simms, Yufik \& Gros, 2010). Negative Valence is likely a generalized dark side trait, such as Honesty/Humility above, but Positive Valence's role in dark personality is less obviously clear.

\section{Dark Personality and Workplace Outcomes}

\section{Dark personality and job performance}

The relationship between job performance and normal personality traits, as represented by the Big Five, has been well established (Barrick \& Mount, 1991). Although dark personality traits have received less attention, a recent meta-analysis (O'Boyle, Forsyth, Banks, \& McDaniel, 2012) investigating the relationship between the Dark Triad and job performance found that both Machiavellianism and Psychopathy were weakly related to poor job performance. In addition, the HDS dimensions have been shown to have substantial incremental validity over the HPI and the NEO-PI-R (Costa \& McCrae, 1992) in a sample of manufacturing executives and military cadets, respectively (Harms, Spain, Hannah, Hogan \& Foster, 2011b). 


\section{Dark personality and citizenship behavior}

Scant research has examined whether dark personality is predictive of positive discretionary behaviors in the workplace; however, a handful of studies have found negative relationships between dark personality and citizenship behaviors. For example, Machiavellianism has been shown to negatively predict with citizenship behaviors toward the organization and citizenship behaviors toward other individuals in the organization (Becker \& O'Hair, 2007). One reason given for this is that Machiavellians tend to be primarily self-interested, so although they engage in impression management with others, they simply do not invest themselves in being concerned with the organization as an entity (Becker \& O'Hair, 2007). At the organization level, research has suggested that the presence of individuals with psychopathic tendencies in leadership positions results in less corporate social responsibility and diminished organizational support for employees (Boddy, Ladyshewsky, \& Galvin, 2010).

\section{Dark personality and counterproductive work behaviors}

Workplace deviance and counterproductive work behaviors (CWBs) are probably the single most popular topic for the study of dark personality in the workplace. This make intuitive sense in terms of theoretically matching predictors to outcomes and the relationship tends to be fairly robust. The HEXACO Honesty-Humility dimension has been consistently shown to predict workplace deviance (e.g., Lee, Ashton, \& de Vries, 2005; Zettler \& Hilbig, 2010). In addition, researchers have found links between the Dark Triad traits and CWBs (cf. O'Boyle, Forsyth, Banks \& McDaniel, 2012; Scherer et al., ). In addition, meta-analytic evidence also suggests a fairly robust relationship between Machiavellianism and unethical decision making in organizations (Kish-Gephart, Harrison, \& Trevino, 2010).

\section{Dark personality and creative performance}

Compared with other domains of performance, creative performance is one of the least studied outcomes of dark personality. That said, Eysenck has provided evidence that the unconventional thinking that accompanies Psychoticism (low agreeableness and low conscientiousness, and associated with a tendency toward psychopathy; Heath \& Martin, 1990) was positively related to creative thinking and performance (Eysenck, 1993; Woody \& Claridge, 1977). Further, research comparing the personalities of artists to nonartists has demonstrated that artists score higher on not only Psychoticism (Götz \& Götz, 1979) but also a variety of schizotypal measures (Burch, Pavelis, Hemsley, \& Corr, 2006).

Other research investigating the link between narcissism and creativity has found that although narcissists tend to claim to be very creative, their creative performance is no better than that of non-narcissists (Goncalo, Flynn, \& Kim, 2010). However, narcissists were rated as more creative when they had a chance to pitch their ideas, largely because of their enthusiasm. With respect to group-level creative outcomes, there was a non-linear relationship whereby optimal creative outcomes were achieved when the group members displayed moderate levels of narcissism (Goncalo, Flynn \& Kim, 2010). The relationship between leader dark personality and subordinate creative performance has not been tested, but there is evidence suggesting that toxic leaders can increase the stress and cognitive load of their subordinates and make them feel less empowered and less willing to take chances or engage in creative activities (Aryee, Chen, Sun, \& Debrah, 2007; Liu, Liao, \& Loi, 2012).

\section{Dark personality and training}

Past theory and research is suggestive that personality plays a major role in determining the receptivity of participants in training programs to learning new skills or changing behaviors (Aguinis \& Kraiger, 2009; Hogan \& Warrenfeltz, 2003). Hogan (2007) has argued that individuals characterized by chronic overcon- 
fidence will be less likely to accept negative feedback and may even be dismissive of it. Harms, Spain, and Hannah (2011a) explored the role of subclinical traits on leader development in longitudinal study of military cadets. In general, dark personality dimensions were negatively associated with change in leadership and also moderated individual growth curves for leader development, such that individuals high in dark side traits developed more slowly. A notable exception was narcissism, which was positively associated with change in leadership, and did not substantially harm individual development. The authors interpreted this as evidence that narcissists may be motivated to "be the best" in their chosen area, so may apply substantial effort in development settings.

\section{Dark personality and interviewing}

It has been argued that individuals with dark personality traits such as Machiavellianism may be more skilled and more willing to engage in faking in employment interviews (Levashina \& Campion, 2006). This hypothesis has been supported by the limited research on dark personality in interview settings. For example, research by Fletcher (1990) as shown that individuals higher in Machiavellianism are more willing to be dishonest during interviews. More recent work focusing on the behavior of narcissists in job interview settings has shown that highly narcissistic individuals are more prone to two behaviors that positively influence ratings of employability: self-promotion and talkativeness (Paulhus, Westlake, Calvez, \& Harms, ). Once again, the advantage of narcissists can be attributed both to their motivation and their skill in performing these behaviors. Moreover, related research has demonstrated that narcissists are particularly effective at creating positive first impressions in groups (Back, Schmulke, \& Egloff, 2010). The ability of narcissists to create these positive impressions may not only benefit individuals in selection settings but also help these individuals self-promote their way into leadership positions (Brunell et al., 2008). That said, it has also been noted that initial positive impressions quickly wear off after prolonged exposure to individuals with noxious personalities and that these individuals will eventually be seen by others as hostile and arrogant (Paulhus, 1998). Consequently, some researchers have argued that dark personality traits, particularly those in the Dark Triad, may represent short-term evolutionary strategies for success (Jonason, Koenig, \& Tost, 2010; McDonald, Donnellan, \& Navarrete, 2012).

\section{Dark personality and leadership}

Recent reviews of the leadership literature have demonstrated that there remains considerable interest in the trait approach to leadership (Hiller, DeChurch, Murase, \& Doty, 2011; Zaccaro, 2012), but the vast majority of this research has focused on variants of the Big Five personality traits (Antonakis, Day, \& Schyns, 2012). Consequently, there have been recent calls for more research focusing on dark personality in order to better understand leadership and leader derailment (Hogan, 1994; Hogan \& Hogan, 2001; Judge et al., 2009).

Reviews linking dark personality and leadership have suggested the relationship is more complex than pointing to dark personality as a derailer. For example, a number of researchers have suggested that narcissistic tendencies can play an important role in both leader successes and failures (e.g Kets de Vries \& Miller, 1985; Rosenthal \& Pittinsky, 2006). Some evolutionary psychologists have even suggested that extreme risk-taking behavior, decried in the media following the recent economic collapse, is often reinforced in organizational leaders in spite of potential dangers because it can be associated with success under benevolent circumstances or in the face of weak opposition (Johnson, Wrangham, \& Rosen, 2002). Khoo and Burch (2008) reported finding negative relationships between transformational leadership ratings and the HDS dimensions of Cautious and Reserved and a positive relationship with HDS Colorful. On the whole, studies linking dark personality to leadership outcomes have been suggestive that context is important as a determinant of whether dark personality traits will play a positive or negative role in leadership effectiveness outcomes (Padilla, Hogan, \& Kaiser, 2007). 
Historiometric studies have also shown a positive link between dark personality and leader effectiveness. For example, Machiavellians are proficient at forming political alliances and cultivating a charismatic image (Deluga, 2001). In a study of 39 U.S. presidents, ratings of Machiavellianism were positively associated with not only charisma but also rated performance (Deluga, 2001). Machiavellian leaders also tended to serve more years in elected office and have a greater number of legislative achievements (Simonton, 1986). Moreover, the success of Machiavellian leaders was significantly enhanced when paired with higher levels of intelligence.

Narcissistic CEOs influence organizational performance (Chatterjee \& Hambrick, 2007; Resick, Whitman, Weingarden, \& Hiller, 2009). These CEOs tend to favor big, bold actions-actions that grab attention. Such actions tend to have large consequences, which can be positive or negative: big wins or big losses (Chatterjee \& Hambrick, 2007). Consequently, organizations with narcissistic CEOs tend to perform in an extreme and fluctuating way; their year-to-year performance is less stable than organizations led by less narcissistic CEOs.

\section{Managerial derailment}

Reviews of managerial derailment have suggested that dark personality traits serve as an important antecedent to leader failures (Hogan \& Hogan, 2001; Leslie \& Van Velsor, 1996; Lombardo, Ruderman \& McCauley, 1988). One potential reason why individuals attain and maintain leadership positions is that their supervisors tend to ignore moral shortcomings when evaluating managerial potential (Cook \& Emmler, 1999) - yet what gets you to the top cannot necessarily keep you there. There are some consistent reasons why executives derail, some of which overlap strongly with dark personality-especially problems with interpersonal relationships (Van Velsor \& Leslie, 1995). This domain is associated with interpersonal styles characterized as insensitive, manipulative, demanding, authoritarian, self-isolating, aloof, or critical (Lombardo \& McCauley, 1994), or arrogance, melodrama, volatility, excessive caution, habitual distrust, aloofness, mischievousness, eccentricity, passive resistance, perfectionism, and eagerness to please (Dotlitch \& Cairo, 2003), which bear more than a passing resemblance to the dimensions assessed by the HDS. Harms, Spain, and Hannah (2011a) framed their study of the dark side and leader development partially from the perspective of derailment, but far more work is needed to determine the role of dark personality in career advancement and derailment processes.

\section{Abusive supervision}

It is natural to consider the relationship between negative aspects of leadership and dark personality (Krasikova, Green, \& LeBreton, 2013; Padilla et al. 2007). It has been suggested that the base rate for managerial incompetence in the United States is between 50 and 75 percent (Hogan, Raskin, \& Fazzini, 1990). Moreover, a number of researchers have pointed to dark personality as a key culprit in the ongoing problems with failed leadership in organizations (Burke, 2006; Dotlitch \& Cairo, 2003; Hogan, 1994; Kets de Vries \& Miller, 1984). It is important to distinguish managers who are simply ineffective/incompetent from managers who are malicious. Krasikova et al. (2013) clarified the differences between ineffective leadership and destructive leadership-leadership actions that have intent to cause some form of harm. Leaders with dispositional characteristics that lead them to impute hostile motives in others (e.g., Skeptical personality and aggressiveness) are more likely to engage in destructive leadership (e.g., Krasikova et al., 2013). For example, Machiavellian leaders are rated as more abusive by their subordinates than low Machiavellians are (Kiazid et al., 2010).

\section{Dark personality and job attitudes/affect}

Although it is well established that the Big Five traits Extraversion and Neuroticism are related to job satisfaction (Judge, Heller, \& Mount, 2002), the relationship between dark personality traits and workplace affect is less well documented. Many of the dark traits tend to be derived from clinical PDs; they are often associated with greater negative affect, so it could be expected that dark traits will generally show negative relationships with job satisfaction. Moreover, as dark traits are frequently related to higher levels of 
interpersonal conflict with supervisors and coworkers, it could be anticipated that they would not find the workplace enjoyable, but there are exceptions to this. For example, although there is evidence that there is a negative relationship between narcissism and job satisfaction as a whole, narcissists in sales positions report greater satisfaction with their jobs than non-narcissists (Soyer, Rovenpor, \& Kopelman, 1999). A recent meta-analysis showed that narcissism, Machiavellianism, and trait anger were all negatively related to job satisfaction (Bruk-Lee, Khoury, Nixon, Goh \& Spector, 2009). However, the meta-analysis was based on a very small number of studies; so there remains a great deal more research needed to better understand the nature of these relationships. Furthermore, the role that dark personality plays in other important domains of workplace affect, such as Affective Events theory (Weiss \& Cropanzano, 1996), is effectively unknown, although we would expect that dark characteristics would directly predict levels of both positive and negative emotions, and moderate responses to specific workplace events. We expect that the patterns may, in fact, be complicated, as a large number of DSM disorders have major affective components, almost all negative: some, such as manic, associated with positive affect, and others, such as psychopathy, where individuals experience little if any self-directed negative affect. Altogether, the role of emotional experiences and abilities in connecting dark personality to workplace outcomes warrants additional research. For example, it has been noted that Machiavellians with low intelligence tend to be unsuccessful because they lack the ability to match their intentions. Could the same be true for emotional intelligence? That is, would Machiavellians be similarly hindered by an inability to read and manipulate the emotions of others?

In addition, understanding the motivational underpinnings of dark traits may inform our understanding of emotional and behavioral reactions to goal blockage. For example, highly dependent individuals, who may be driven by Need for Affiliation, would be expected to react to interpersonal rejection with despair, whereas narcissists, who are typically driven by Need for Power, may react with anger (McClelland, 1985). Although the trigger event may be the same, the emotional experience and resulting behavior could be better understood through an integration of dark personality traits and their relationships with various latent motives (cf. Bing, et al., 2007a; James \& LeBreton, 2010; 2012; Winter, John, Stewart, Klohnen \& Duncan, 1998).

\section{Dark personality and negotiations}

Although there is very limited research documenting relationships between dark personality characteristics and negotiation, dark traits may play an important role in this unique context. Christie and Geis (1970) have reported extensive evidence that Machiavellians are highly successful negotiators-moreover, Machiavellians seemed to enjoy the combative nature of the negotiating process more than others. Greenhalgh and Gilkey (1997) have reported some qualitative evidence that narcissists tend to exasperate, abuse, and antagonize negotiation partners rather than gather information and adopt an intransigent stance. Further, narcissists show little empathy in negotiations and argue only from their own interests. Wu (2010) found that all three components of the Dark Triad were associated with willingness to use unethical tactics in negotiations in two hypothetical settings. However, less support was found that they would actually use unethical tactics in a face-to-face negotiation task. Similarly, a study investigating the role of the Dark Triad as an antecedent of influence tactics (Jonason, Slomski, \& Partyka, 2012) found that both psychopathy and Machiavellianism were associated with an increased use of hard tactics (e.g., threats and attempts at manipulation) whereas Machiavellianism and narcissism were associated with soft tactics (e.g., ingratiation, offering to exchange a favor, and compromise). In particular, psychopaths favor threats, Machiavellians favor manipulation of others, and narcissists try to use their appearance and charm to influence others.

\section{A Taxonomy of Dark Personality Traits?}

A major lacuna in the study of the dark side of personality is the lack of a generally accepted taxonomy of dark personality traits. Most work thus far as focused on either the Dark Triad or the DSM-IV PDs. Nei- 
Spain, Harms, \& Lebreton in Journal of Organizational Behavior (2013)

ther of these approaches is particularly edifying - they are essentially descriptions of typically toxic behavioral patterns and may not reasonably reflect the deep structure that drives dark side behavior (e.g., implicit motives and defense mechanisms; James \& LeBreton, 2010; 2012). Understanding the motives, perceptions, and ability complexes that underlie dark personality could help clarify the relationships between dark personality and overt workplace behavior (Horowitz et al., 2006; Wu \& LeBreton, 2011). For instance, psychopathy seems to be at least partially determined by low ability to empathize with others, but are psychopaths also actively motivated to cause harm, or do they perceive the world as particularly hostile or untrustworthy? Similarly, it is noted that Machiavellians are motivated to manipulate others, but not all Machiavellians may be especially able to do so-is it possible that an interaction between motives and ability might have important consequences for Machiavellians' effectiveness (e.g., in negotiations, interviews, or sales pitches)?

\section{Dark intentions and dark outcomes}

We wish to make a distinction inspired by Krasikova, Green, and LeBreton's (2013) model of destructive leadership-destructive intentions and destructive outcomes (Krasikova et al. distinguished between destructive actions and destructive intentions). Consider, for example, the classic narcissist whose motives can essentially be characterized as self-elevation via other-dominance (Horowitz et al., 2006). That is, the narcissist has a potentially destructive intention - to make others feel small, but it will not necessarily result in a negative outcome. Consider, on the other hand, an individual with histrionic tendencies. This person may have no intention to cause harm to others, but the obsessive need for attention they display may be extremely disruptive and lead to negative outcomes.

This makes it clear that there are at least two ways that a personality characteristic can be called "dark" - in its nature or in its effects (this is in some ways the primary difference between the Dark Triad [intent] and the HDS [effects]). We can claim that a personality concept is dark if it has a particularly malevolent character-individuals who have high elevations on the construct are motivated (consciously or unconsciously) to harm others (or themselves). On the other hand, a characteristic that has no particularly malevolent content could still have noxious consequences. Individuals who are histrionic or schizotypal may have little-to-no motivation to harm, control, or dominate others, but their actions may have distinctly unpleasant, debilitating, or unintentionally but decidedly harmful effects on themselves or others. Any taxonomy of dark characteristics needs to respect this distinction. Harm, of some kind, is almost a necessary consequence of the label dark.

\section{Understanding the many approaches}

There are several existing taxonomies for dark personality, whose terminologies are not mutually intelligible, that is, it is not always clear when the different taxonomies are talking about the same or different concepts. We have focused mostly on the Dark Triad and the HDS, as these are generally well established, but we need mention aberrant personality (a six-dimensional approach constructed from the NEO-PI-R and based on the DSM-IV Axis II disorders; Wille, De Fruyt, \& De Clerq, 2013), maladaptive personality (primarily the Dark Triad; Wu \& LeBreton, 2011), or dysfunctional personality (similar in scope to the HDS, again based on DSM-IV Axis II disorders; Moscoco \& Salgado, 2004). The Dark Triad perspective is the most prevalent in both personality psychology and organizational research (O'Boyle, Forsyth, Banks, \& McDaniel, 2012). The HDS/DSM-IV approach has some traction (De Fruyt et al., 2009; Harms et al., 2011a; 2011b) but is more commonly used by practitioners.

We recommend against focusing solely on the Dark Triad, not only because it leaves out substantial areas of the subclinical domain captured by the HDS dimensions, but also because it was never intended as a taxonomy of dark characteristics (Paulhus \& Williams, 2002). Further, it is important for organizational researchers to pay attention to a broader set of dark side elements than the Dark Triad (e.g., odd/eccentric or avoidant styles) that could predict outcomes distinctly from the Dark Triad (Wille, De 
Fruyt \& De Clerq, 2013). Furthermore, the main approaches to assessing dark personality constructs vary in level of generality. That is, at the most general end, honesty-humility and negative valence seem to assess very broad, general tendencies toward the dark side. The Dark Triad assesses a complex of noxious personality characteristics. The HDS provides a dimensional taxonomy to dark side characteristics. Investigators can tailor their assessments to their research questions, on the basis of the compatibility principle (Ajzen, 1988). For instance, if the investigator is primarily interested in predicting a broad outcome, say CWBs, using dark personality, that investigator may wish to use a broad measure of dark personality, such as honesty-humility, but if the investigator was concerned with a fine-grained behavior, such as coercive influence tactics in negotiations, that investigator would prefer at least the Dark Triad, if not the HDS/DSM.

\section{Dark personality and the DSM-5}

In addition, the transition from the DSM-IV to the DSM-5 represents a potential breakthrough in the understanding of the nature of dark personality (Krueger et al., 2011a; Krueger et al., 2011b). Until recently, clinical approaches to studying PDs were based on the assumption that PDs were categorical in nature. There is mounting evidence that PDs are dimensional in nature (e.g., Eaton, Krueger, South, Simms, \& Clark, 2011). Consequently, the categorical model resulted in measurements suffering from high comorbidity, low reliability, and artificial thresholds for diagnosis (Krueger et al., 2011b; Trull \& Durrett, 2005). The new DSM-5 restructures what is known about PDs into six core PD domains (negative affectivity, detachment, antagonism, disinhibition, and psychoticism) that are then divided in to 25 facet traits (e.g., hostility, suspiciousness, impulsivity, and eccentricity) that are conceptually and empirically distinct (Krueger et al., 2011b). This new model can be used to integrate the DSM-IV PDs and those outside the DSM-IV (e.g., Machiavellianism) and describe them in terms of composites of the new DSM-5 traits. For example, it is much more intuitive and appealing to describe Machiavellians as being high on deceitfulness and manipulativeness (DSM-5) than highly disagreeable and low on conscientiousness (Big Five) or simply having no obvious place in the theoretical taxonomy (DSM-IV or HDS).

Research has begun comparing dark personality traits with the new DSM-5 model. For example, an analysis of the subfacets of narcissism revealed that grandiose narcissism is highly related to DSM-5 Antagonism whereas vulnerable narcissism is more highly related to DSM-5 Negative Affectivity (Miller et al., in press). That said, to date, there is no research we are aware of investigating the relationships between the DSM-5 traits and workplace outcomes. Given that research using dark traits has already produced substantial results, it seems that further research is warranted with a more complete taxonomy and more distinct variables. It is possible that the effects reported in the research to date represent a conservative estimate of the importance of dark personality traits in the workplace.

\section{Dark traits and the psychological unconscious}

Dark tendencies may also have an unconscious aspect (e.g., implicit motive to aggress; implicit motive for power; cf. James \& LeBreton, 2010; 2012; James et al., 2013). Thus, in addition to recognizing the importance of dark intentions and the utility of existing taxons such as the HDS/DSM framework, we also encourage scholars to consider the motivational underpinnings of behavior. A growing body of literature has found that traits (dark or bright) often serve as a "channel" for the expression of implicit motives (Bing et al., 2007a; Bing et al., 2007b; James \& LeBreton, 2012; McClelland, Koestner, \& Weinberger, 1989; Winter, John, Stewart, Klohnen, \& Duncan, 1998). Whereas there is reasonable agreement about the structure of bright traits (i.e., Big Five) and there is growing consensus concerning dark traits (i.e., HDS/DSM; Dark Triad), the nomological topography of the psychological unconscious remains largely unmapped. Contemporary researchers have relit the torches first lit by Murray (1938). As such, we are seeing progress toward a better understanding of unconscious processes and motives (cf. Cramer, 2006; De Houwer, Teige-Mocigemba, Spruyt, \& Moors, 2009; Epstein, 1994; Fazio \& Olson, 2003; James \& LeBreton, 2012; Kihlstrom, 1999; Wilson \& Brekke, 1994).

Nevertheless, one area that is ripe for future research involves the extensive mapping of the psychological unconscious, with a particular focus on the dark aspects. Likewise, future research should examine not only how traits might channel the expression of latent motives but how latent motives might 
also interact with one another to engender problematic work behavior. For example, James et al. (2013) have hypothesized that the implicit need for power is inherently valence neutral (neither good nor bad). The need for power only becomes problematic when coupled with a negative motive, such as the motive to aggress (i.e., to cause harm). In such instances, we are likely to witness the birth of a toxic leader. Measuring these latent motives is a challenge, and we next review various approaches to indirect measurement of dark traits.

\section{Measurement Issues}

In personality assessment, there is concern that individuals can easily fake good (Morgeson et al., 2007), especially with measures that are highly transparent, such as the HEXACO or Dark Triad scales. Some have argued that this is not a concern in normal personality assessment (e.g., Hogan, Hogan, \& Roberts, 1996), but it may be unwise to assess dark personality with strictly self-report measures. Also, short measures of personality should generally be avoided (Credé, Harms, Nierhorster, \& Gaye-Valentine, 2012) - short measures are often overly homogeneous and are therefore extremely narrow bandwidth measures, severely hampering their ability to predict behavior (Yarkoni, 2010). Jonason and Webster (2010) introduced the "Dirty Dozen" as a very brief measure of the Dark Triad. Not only did their initial research suggest significant problems with their four-item measure of Machiavellianism (it correlated more highly with other measures than the original Machiavellianism scales), but later investigations (Miller, Few, Seibert, Watts, Zeichner, \& Lynam, in press) found significant problems with the construct validity of their fouritem Psychopathy measure as well.

\section{Subtle assessment}

This review of dark personality has focused largely on the explicit or conscious aspects of dark personality traits. Explicit personality assesses mental representations of behavior and motivation that are accessible to introspection (James \& LeBreton, 2012). Researchers interested in explicit personality have tended to focus on self-report surveys asking about how respondents typically think, feel, or act. Complementing this approach is implicit personality, which assesses aspects of motivation that are not accessible to introspection (James \& LeBreton, 2012). Because the implicit personality operates outside of conscious awareness, researchers cannot rely on direct assessment devices such as self-report surveys. Instead, researchers must invoke indirect assessment devices (Greenwald \& Banaji, 1995; James \& LeBreton, 2012). These tests may be less susceptible to faking (James \& LeBreton, 2010), but the question remains as to whether these are the best solutions available.

\section{Measuring dark personality with normal-range measures}

Appropriately combined items from normal-range personality measures can be effective in assessing aspects of dark personality (De Fruyt et al., 2009). Measures constructed in this way can predict work and career outcomes (De Fruyt et al., 2009; Wille et al., 2013). This approach is based on the overlap of the five-factor model with dark personality. Facet-level measurements for the five-factor model can be used as indicators of dark personality characteristics (Miller, Bagby, Pilkonis, Reynolds, \& Lynam, 2005). For instance, the schizoid count consists of the sum of the scores on the six NEO-PI-R Extraversion facets, O3, openness to feelings (reversed), and O4, openness to actions (reversed; De Fruyt et al., 2009, Wille et al, 2013). This approach appears to capture what the PDs are about as well as a complicated prototypematching approach (Miller et al., 2005; De Fruyt et al., 2009; Wille et al., 2013). This approach has the advantage that the assessment is a normal personality test, which should not engender too much suspicion from test takers but may not give a complete assessment of the dark side, as it focuses on elements that are common with normal-range personality. 
Reports by knowledgeable others

When it comes to normal personality, other people may be particularly good sources of information (Connelly \& Ones, 2010). In the dark personality realm, Thomas, Turkheimer, and Oltmanns (2003) have shown that peer-nominations are an effective means by which to avoid the problems typically found with self-report measures in the prediction of real world behavior. If dark personality is of interest, reports from knowledgeable others should be considered. As Hogan (2007) has pointed out, those who are exposed to individuals with dark personalities are more than capable of reporting on their patterns of destructiveness. However, it is worth noting that knowledgeable others still do not have access to an individual's inner thoughts, which can be a problem for accurate assessment of dark side characteristics. For instance, the most widely used Machiavellianism instrument is largely attitudinal, which may be difficult for peers to report. Moreover, it is possible for a high-Mach to appear friendly and trusting on the surface but have a hidden agenda or masking a deep-seated cynicism. Similarly, a variety of Axis II characteristics may not be displayed unless the individual is under considerable strain. That is to say, it is possible that other-reports of dark personality may be most applicable for primarily interpersonal or easily displayed traits. Which characteristics are well suited for other-report and in which circumstances other-reports work well for dark personality are open research questions. Answers to these questions could aid in interviewing or interpreting references for individuals with dark personality characteristics.

\section{Conditional reasoning tests}

Conditional reasoning tests (CRTs) are predicated on the idea that the perceptual schemata that individuals use to interpret the world around them differ for different levels of various implicit motives. Individuals with particular motives invoke unique profiles of justification mechanisms (implicit cognitive biases used to justify or rationalize behavior; James, 1998). For instance, individuals who are dispositionally aggressive are likely to view the world as hostile because they impute hostile motives for (i.e., they have a hostile attribution bias; James \& LeBreton, 2010). Justification mechanisms linked to implicit motives may be measured by asking individuals to solve inductive reasoning problems. These items are different from reasoning problems designed to measure intelligence. Specifically, each item contains multiple correct answers: one that is reflective of a justification mechanism (e.g., hostile attribution bias) and one that is not (James, 1998). These tests are referred to as CRTs because the probability that an individual selects the answer on the basis of a justification mechanism depends on his or her personality (e.g., aggressive vs. non-aggressive). Thus, CRTs indirectly assess biases used to justify motive-driven behavior.

The use of CRTs for assessing aggression has been extensively studied (CRT-A; James, 1998; James \& LeBreton, 2012; James \& McIntyre, 2000; LeBreton, Barksdale, Robin \& James, 2007). Scores on the CRTA have been shown to predict aggression and CWBs well and correctly identify most people as non-aggressive (James \& McIntyre, 2000). When the true purpose of the exam is hidden, test takers do not seem to manipulate their scores, even when they are instructed to respond like job applicants (LeBreton et al., 2007). Consequently, there are no substantial differences in CRT-A scores between students, job applicants, and job incumbents (LeBreton, Barksdale, Robin \& James, 2007). The evidence of the validity and relative fake resistance of the CRT-A seems to indicate that the CRT method is worthy of additional research. However, their faking resistance seems to be largely a function of their true purpose being hidden, so widespread use could compromise their utility.

\section{Discussion}

\section{Implications for personnel selection and training}

Although the dark side of personality can provide incremental knowledge about employees, the role that such traits can play in personnel selection is questionable. First, it is unlikely that individuals who have 
high elevations on a number of these traits will respond honestly to self-report assessments used in selection situations. Second, it is not always clear that such assessments are compliant with the Americans with Disabilities Act (Wu \& LeBreton, 2011). Some subtle assessments, such as CRTs, may help to identify motive or perception patterns that are problematic but not protected (cf. James \& LeBreton, 2012).

Regardless of potential issues in using these assessments in selection, dark traits may be useful in training and development. At the simplest, it would be unwise to try to build a team out of three people who are all high on psychopathy or aggression (Baysinger, Scherer \& LeBreton, ). In a more complex application, individual development plans could be constructed that take into account the weaknesses the individual employee has. In some cases, this could be used to mitigate against problems that the trait causesfor instance, skeptical personalities being suspicious of, and unwilling to accept, feedback (Harms, Spain \& Hannah, 2011a).

There is concern about whether dark personality and the behavioral patterns associated with it can change (Burke, 2006). Evidence has accumulated for lifespan developmental trends in bright side personality (Roberts et al., 2006a; Roberts, Walton, \& Veichtbauer, 2006b) - can the same be said for dark personality traits? Hogan, Curphy, and Hogan (1994) suggested that change in dark side characteristics is possible. Furthermore, there is extensive evidence that interventions targeted at personality factors can decrease juvenile delinquency, criminal behavior, and recidivism (Hill, Roberts, Grogger, Guryan, \& Sixkiller, 2011). This suggests the possibility that organizational interventions focused on dark personality can help reduce negative outcomes such as CWBs or abusive supervision. However, work with juveniles is hardly conclusive evidence that such interventions would be effective in the workplace. Interventions may need to focus on the consequences of dark personality more so than changing personality itself.

\section{Future directions}

Most research using dark personality has been limited to few topics and settings. There is considerable research on the role that dark personality characteristics play in CWB and in leadership, particularly destructive supervision and managerial derailment. This alignment of dark predictors with negative outcomes makes sense, but it leaves extensive areas wide open for study.

First, most of the work in organizational research uses the Dark Triad as an organizing framework, which unfortunately omits a considerable segment of the subclinical domain. Second, dark personality needs to be studied more in reference to bright outcomes, which should pay special attention to boundary conditions. For instance, the popular coverage of dark personality suggests that there may be some positive aspects to having a CEO who is narcissistic or psychopathic (e.g., Dutton, 2012). We suspect that the long-term interpersonal problems associated with dark personality make that unlikely (Hogan \& Hogan, 2001), but most dark traits have both an upside and a downside. Is it always the case that the downside trumps the upside? Are there situations where it might be useful to have some level of dark side traits? Kaiser, LeBreton, and Hogan (under review) recently found that the extreme levels of dark traits (both too much and too little) are problematic for leaders (especially those who are low in emotional stability). These findings suggest that some modest level of dark traits may be ideal.

Individuals with elevation on any of the Dark Triad may be willing to engage in unethical behavior, but it is an open question under what circumstances they actually do so. Given that high-Machs are willing to manipulate people but may not be able to do so, do they truly demonstrate skill in negotiations? Might narcissistic leaders' need to make themselves look good be manifested in attempts to secure advantages and recognition for their team if they identify closely with the unit? These are open questions in need of further investigation.

Job performance seems like another worthwhile target. It seems that dark personality can substantially improve the prediction of performance (Harms, Spain, Hannah, Hogan \& Foster, 2011b), but the focus of organizational research thus far has been primarily on workplace deviance to the neglect of positive discretionary behaviors, task performance, and creative performance. Beyond performance outcomes, there are numerous organizational outcomes where the role of dark personality remains almost entirely unexplored. An example is turnover-we know that individuals with Axis II disor- 
ders are more likely to be recently laid off or laid off for long periods or to have trouble with their supervisor if they are working (Ettner, Maclean \& Frech, 2011), so their work status seems like a worthwhile question.

\section{Nonlinearity of effects}

The theoretical background of the dark side of personality suggests that the strategies these personality characteristics embody should be effective under some set of circumstances, such as short-duration relationships. For instance, Hogan and Hogan (2001) hypothesized that some moderate level of a dark side trait may be most beneficial, implying a quadratic functional form for the relationship between dark side characteristics and many outcomes (cf. Benson \& Campbell, 2007; Kaiser et al., under review). Further, the theory suggests a dissociation in effects for similar jobs with different time horizons (e.g., teller vs. relationship banker). These points suggest two research strategies for future investigations on the question of the relative costs and benefits of dark side traits: large, representative samples with adequate range of dark side traits and work behavior, and targeted studies aiming to tease apart their effects across shortand long-term time horizons.

\section{Conclusion}

Dark personality represents a naturally intriguing aspect of day-to-day functioning, as evidenced by the cursory review of popular coverage on the topic at the beginning of this article. These characteristics seem to be helpful in explaining a wide range of work behavior, some dark and some normal. Additionally, there could be dividends paid from investing in this area. It is clear that dark personality is only sometimes negative; understanding how dark personality characteristics' effects are moderated could help us to build more effective theories of individual differences, generally. That is, attempting to understand when dark personality characteristics have the good or more-expected bad consequences may help us to understand specific work contexts more clearly.

\section{The Authors}

Seth M. Spain is an Assistant Professor of Organizational Behavior at SUNY Binghamton. He received his $\mathrm{PhD}$ from the University of Illinois. His research focuses on the assessment of individual differences and their role in leadership and the development of statistics for addressing dynamic hypotheses.

Peter D. Harms is an Assistant Professor of Management at University of Nebraska-Lincoln. He received his PhD in Personality Psychology from the University of Illinois. He specializes in applied personality, and his research focuses on the role that individual differences play in organizational behavior and leadership.

James M. LeBreton is a Professor of Psychology at Pennsylvania State University. He received his PhD from the University of Tennessee. His research focuses on the assessment of implicit personality and the development of statistical methods for organizational research.

\section{References}

Aguinis, H., \& Kraiger, K. (2009). Benefits of training and development for individuals and teams, organizations, and society. Annual Review of Psychology, 60, 451-474.

Ajzen, I. (1988). Attitudes, personality, and behavior. Homewood, IL: Dorsey Press.

Allport, G. W., \& Odbert, H. S. (1936). Trait names: A psycho-lexical study. Psychological Monographs, 47, 211.

American Psychological Association (1994). Diagnostic and statistical manual of mental disorders (4th ed.). Washington, D.C.: American Psychological Association.

Antonakis, J., Day, D. V., \& Schyns, B. (2012). Leadership and individual differences: At the cusp of a renaissance. The Leadership Quarterly 23, 643-650. 
Aryee, S., Chen, Z., Sun, L., \& Debrah, Y. (2007). Antecedents and outcomes of abusive supervision: Test of a trickledown model. Journal of Applied Psychology, 92, 191-201.

Ashton, M. \& Lee, K. (2009). The HEXACO-60: A short measure of the major dimensions of personality. Journal of Personality Assessment, 91, 340-345.

Ashton, M., Lee, K., Perugini, M., Szarota, P., de Vries, R., Di Blas, L., Boies, K., De Raad, B. (2004). A six-factor structure of personality-descriptive adjectives: Solutions from psycholexical studies in seven languages. Journal of Personality and Social Psychology, 86, 356-366.

Babiak, P., \& Hare, R. (2006). Snakes in suits: When psychopaths go to work. New York: Regan Books.

Back, M. D., Schmulke, S. C., \& Egloff, B. (2010). Why are narcissists so charming at first sight? Decoding the narcissism- popularity link at zero acquaintance. Journal of Personality and Social Psychology, 98, 132-145.

Barrick, M., \& Mount, M. (1991). The Big Five personality dimensions and job performance: A meta-analysis. Personnel Psychology, 44, 1-26.

Baysinger, M., Scherer, K. T., \& LeBreton, J. M. (under review). Exploring the disruptive effects of psychopathy and aggression on group processes and group performance. Manuscript invited for 2nd revision and resubmission at Journal of Applied Psychology.

Becker, J., \& O'Hair, H. D. (2007). Machiavellians' motives in organizational citizenship behavior. Journal of Applied Communication Research, 35, 246-267.

Benet-Martinez, V., \& Waller, N. G. (2002). From adorable to worthless: Implicit and self-report structure of highly evaluative personality descriptors. European Journal of Personality, 6, 1-41.

Benson, M., \& Campbell, J. (2007). To be, or not to be, linear: An expanded representation of personality and its relationship to leadership performance. International Journal of Selection and Assessment, 15, 232-249.

Bing, M. N., LeBreton, J. M., Davison, H. K., Migetz, D. Z., \& James, L. R. (2007a). Integrating implicit and explicit social cognitions for enhanced personality assessment: A general framework for choosing measurement and statistical methods. Organizational Research Methods, 10, 136-179.

Bing, M. N., Stewart, S. M., Davison, H. K., Green, P. D., McIntyre, M. D., \& James, L. R. (2007b). An integrative typology of personality assessment for aggression: Implications for predicting counterproductive workplace behavior. Journal of Applied Psychology, 92, 722-744.

Boddy, C., Ladyshewsky, R., \& Galvin, P. (2010). The influence of corporate psychopaths on corporate social responsibility and organizational commitment to employees. Journal of Business Ethics, 97, 1-19.

Bruk-Lee, V., Khoury, H., Nixon, A., Goh, A., \& Spector, P. (2009). Replicating and extending past personality/job satisfaction meta-analyses. Human Performance, 22, 156-189.

Brunell, A. B., Gentry, W. A., Campbell, W. K., Hoffman, B. J., Kuhnert, K. W., \& DeMarree, K. G. (2008). Leader emergence: The case of the narcissistic leader. Personality and Social Psychological Bulletin, 34, 1663-1676.

Burch, G., Pavelis, C., Hemsley, D., Corr, D. (2006). Schizotypy and creativity in visual artists. British Journal of Psychology, 97, 177-190.

Burke, R. (2006). Why leaders fail: Exploring the dark side. International Journal of Manpower, 27, 91-100.

Campbell, W. K., Hoffman, B. J., Campbell, S. M., \& Marchiso, G. (2011). Narcissism in organizational contexts. Human Resource Management Review, 21, 268-284.

Chamorro-Premuzic, T., von Stumm, S., \& Furnham, A. (2011). The Wiley-Blackwell handbook of individual differences. Malden, MA: Wiley-Blackwell.

Chatterjee, A., \& Hambrick, D. C. (2007). It's all about me: Narcissistic chief executive officers and their effects on company strategy and performance. Administrative Science Quarterly, 52, 351-386.

Christie, R., \& Geis, F. L. (1970). Studies in Machiavellianism. New York, NY: Academic Press.

Cleckley, H. M. (1976). The mask of sanity: An attempt to clarify some issues about the so-called psychopathic personality (5th Ed.). St. Louis, MO: Mosby.

Cook, T., \& Emmler, N. (1999). Bottom up versus top down evaluations of candidates' managerial potential: An experimental study. Journal of Occupational and Organizational Psychology, 72, 423-440.

Connelly, B. S., \& Ones, D. S. (2010). An other perspective on personality: Meta-analytic integration of observers' accuracy and predictive validity. Psychological Bulletin, 136, 1092-1122.

Costa, P. T., \& McCrae, R. R. (1992). Revised NEO personality inventory and five-factor inventory professional manual. Odessa, FL: Psychological Assessment Resources.

Cramer, P. (2006). Protecting the self: Defense mechanisms in action. New York, NY: Guilford Press.

Credé, M., Harms, P. D., Nierhorster, S., \& Gaye-Valentine, A. (2012). An evaluation of the consequences of using short measures of the Big Five personality traits. Journal of Personality and Social Psychology, 102, 874-888.

De Fruyt, F., De Clerq, B. J., Miller, J., Rolland, J.-P., Jung, S.-C., Taris, R., Furnham, A. \& van Hiel, A. (2009). Assessing personality at risk in personnel selection and development. European Journal of Personality, 23, 51-69.

De Houwer, J., Teige-Mocigemba, S., Spruyt, A., \& Moors, A. (2009). Implicit measures: A normative analysis and review. Psychological Bulletin, 135, 347-368. 
Deluga, R. (2001). American presidential Machiavellianism: Implications for charismatic leadership and rated performance. The Leadership Quarterly, 12, 339-363.

Dotlitch, D. \& Cairo, P. (2003). Why CEOs fail: The 11 behaviors that can derail your climb to the top and how to manage them. San Francisco, CA: Jossey-Bass.

Durrett, C., \& Trull, T. J. (2005). An evaluation of evaluative personality terms: A comparison of the Big Seven and Five-Factor Model in predicting psychopathology. Psychological Assessment, 17, 359-368.

Dutton, K. (2012). The wisdom of psychopaths: What saints, spies, and serial killers can teach us about success. New York: Scientific American.

Eaton, N., Krueger, R., South, S., Simms, L. J., \& Clark, L. (2011). Contrasting prototypes and dimensions in the classification of personality pathology: Evidence that dimensions, but not prototypes, are robust. Psychological Medicine, 41, 1151-1163.

Epstein, S. (1994). Integration of the cognitive and the psychodynamic unconscious. American Psychologist, 49, 709-724.

Ettner, S., Maclean, S. C., \& French, M. (2011). Does having a dysfunctional personality hurt your career? Axis II personality disorders and labor market outcomes. Industrial Relations, 50, 149-173.

Eysenck, H. J. (1993). Creativity and personality: Suggestions for a theory. Psychological Inquiry, 4, 147-178.

Fazio, R. H., \& Olson, M. A. (2003). Implicit measures in social cognition research: Their meaning and uses. Annual Review of Psychology, 54, 297-327.

Fletcher, C. (1990). The relationship between candidate personality, self-presentation strategies, and interviewer assessments in selection interviews: An empirical study. Human Relations, 43, 739-749.

Ghaemi, N. (2011). A first rate madness: Uncovering the links between leadership and mental illness. New York, NY: Penguin Books.

Goldberg, L. R. (1981). Language and individual differences: The search for universals in personality lexicons. In L. Wheeler (Ed.), Review of Personality and Social Psychology (Vol. 2). Beverly Hills, CA: Sage.

Goncalo, J., Flynn, F., \& Kim, S. (2010). Are two narcissists better than one? The link between narcissism, perceived creativity, and creative performance. Personality and Social Psychology Bulletin, 36, 1484-1495.

Götz, K. O., \& Götz, K. (1979). Personality characteristics of professional artists. Perceptual E Motor Skills, 49, $327-334$.

Greenhalgh, L., \& Gilkey, R. W. (1997). Clinical assessment methods in negotiation research: The study of narcissism and negotiator effectiveness. Group Decision and Negotiation, 6, 289-316.

Greenwald, A. G., \& Banaji, M. R. (1995). Implicit social cognition: Attitudes, self-esteem, and stereotypes. Psychological Review, 102, 4-27.

Hare, R. D. (1985). Comparison of procedures for the assessment of psychopathy. Journal of Consulting and Clinical Psychology, 53, 7-16.

Hare, R. D. (1999). Without conscience: The disturbing word of the psychopaths among us. New York, NY: Guilford.

Harms, P. D., Spain, S. M., \& Hannah, S. T. (2011a). Leader development and the dark side of personality. The Leadership Quarterly, 22, 495-509.

Harms, P. D., Spain, S. M., Hannah, S. T., Hogan, J., \& Foster, J. W. (2011b). You underestimate the power of the dark side: Subclinical traits, the Big 5, and performance. Chicago, IL: Presented at the Society for Industrial and Organizational Psychology annual conference.

Heath, A. C., \& Martin, N. G. (1990). Psychoticism as a dimension of personality: A multivariate genetic test of Eysenck and Eysenck's psychoticism construct. Journal of Personality and Social Psychology, 58, 111-121.

Hill, P. L., Roberts, B. W., Grogger, J. T., Guryan, J., \& Sixkiller, K. (2011). Decreasing delinquency, criminal behavior, and recidivism by intervening on psychological factors other than cognitive ability: A review of the intervention literature. NBER Working Paper No. 16698. Cambridge, MA: National Bureau of Economic Research.

Hiller, N., DeChurch, L., Murase, T., Doty, D. (2011). Searching for outcomes of leadership: A 25-year review. Journal of Management, 37, 1137-1177.

Hogan, R. (1994). Trouble at the top: Causes and consequences ofmanagerial incompetence. Consulting Psychology Journal, 46, 9-15.

Hogan, R. (2007). Personality and the fate of organizations. Mahwah, NJ: Lawrence Erlbaum Associates, Inc.

Hogan, R., Curphy, G. J., \& Hogan, J. (1994). What we know about leadership: Effectiveness and personality. American Psychologist, 49, 493-504.

Hogan, R., \& Hogan, J. (2001). Assessing leadership: A view from the dark side. International Journal of Selection and Assessment, 9, 40-51.

Hogan, R., \& Hogan, J. (2009). Hogan Development Survey manual (3rd Ed.). Tulsa, OK: Hogan Assessment Systems.

Hogan, R., Hogan, J., \& Roberts, B. W. (1996). Personality measurement and employment decisions: Questions and answers. American Psychologist, 51, 469-477.

Hogan, R., \& Kaiser, R. (2005). What we know about leadership. Review of General Psychology, 9, 169-180.

Hogan, R. \& Warrenfeltz, R. (2003). Educating the modern manager. Academy of Management Learning and Education, 2, $74-84$. 
Hogan, R., Raskin, R., \& Fazzini, D. (1990). The dark side of charisma. In K. E. Clark (Eds.) Measures of leadership (pp. 343-354). West Orange, NJ: Leadership Library of America.

Horowitz, L. J., Wilson,K. R., Turan, B., Zolotsev, P., Constantino,M. J.,\&Henderson, L. (2006). Howinterpersonal motives clarify the meaning of interpersonal behavior: A revised circumplex model. Personality and Social Psychology Review, 10, 67-86.

Hough, L. M., \& Ones, D. S. (2001). The structure, measurement, validity, and use of personality variables in industrial, work, and organizational psychology. In N. Anderson, D. S. Ones, H. K. Sinangil, \& C. Viswesvaran (Eds.) Handbook of industrial, work, and organizational psychology (Vol. 1, pp. 233-277). Thousand Oaks, CA: Sage.

James, L. R. (1998). Measurement of personality via conditional reasoning. Organizational Research Methods, 1, $131-163$.

James, L. R., \& LeBreton, J. M. (2010). Assessing aggression using conditional reasoning. Current Directions in Psychological Science, 19, 30-35.

James, L. R., \& LeBreton, J. M. (2012). Assessing the implicit personality through conditional reasoning. Washington, D. C.: American Psychological Association.

James, L. R., LeBreton, J. M., Mitchell, T. R., Smith, D. R., Desimone, J. A., Cookson, R., ...Lee, H. J. (2013). Use of conditional reasoning to measure the power motive. R. S. Landis and J. M. Cortina (Eds.), Frontiers of methodology in organizational research.

James, L. R., \& McIntyre, M. D. (2000). Conditional Reasoning Test of Aggression test manual. Knoxville, TN: Innovative Assessment Technology.

Jonason, P., Koenig, B., \& Tost, J. (2010). Living a fast life: The Dark Triad and life history theory. Human Nature, 21, 428-442.

Jonason, P., Slomski, S., \& Partyka, J. (2012). The Dark Triad at work: How toxic employees get their way. Personality and Individual Differences, 52, 449-453.

Jonason, P., \& Webster, G. (2010). The dirty dozen: A concise measure of the Dark Triad. Psychological Assessment, 22, 420-432.

Jones, D. N., \& Paulhus, D. L. (2009). Machiavellianism. In M. R. Leary and R. H. Hoyle (Eds.). Handbook of individual differences in social behavior (pp. 93-108). New York, NY: Guilford.

John, O., \& Robins, R., Pervin, L. (Eds.) (2008). Handbook of personality: Theory and research. New York: The Guilford Press.

Johnson, D., Wrangham, R., Rosen, S. (2002). Is military incompetence adaptive? An empirical test with risk-taking behavior in modern warfare. Evolution and Human Behavior, 23, 245-264.

Judge, T., Heller, D., \& Mount, M. (2002). Five-Factor Model of personality and job satisfaction: A meta-analysis. Journal of Applied Psychology, 87, 530-541.

Judge, T. A., Piccolo, R., \& Kosalka, T. (2009). The bright side and dark side of leader traits: A review and theoretical extension of the leader trait paradigm. The Leadership Quarterly, 20, 855-875.

Kaiser, R., LeBreton, J.M., \& Hogan, J. (under review). The dark side of personality and ineffective leadership. Applied Psychology: An International Review.

Kets de Vries, M., \& Miller, D. (1984). Neurotic style and organizational pathology. Strategic Management Journal, 5, 35-55.

Kets de Vries, M., \& Miller, D. (1985). Narcissism and leadership: An object relations perspective. Human Relations, 38, 583-601.

Kihlstrom, J. F. (1999). The psychological unconscious. In L. A. Pervin \& O. P. John (Eds.), Handbook of personality: Theory and research (2nd ed.) (pp. 424-442). New York: Guilford Press.

Khoo, H., \& Burch, G. (2008). The 'dark side' of leadership personality and transformational leadership: An exploratory study. Personality and Individual Differences, 44, 86-97.

Kiazid, K., Restubog, S., Zagenczyk, T. \& Kiewitz, C. (2010). In pursuit of power: The role of authoritarian leadership in the relationship between supervisors' Machiavellianism and subordinates' perceptions of abusive supervisory behavior. Journal of Research in Personality, 44, 512-519.

Kish-Gephart, J., Harrison, D., \& Trevino, L. (2010). Bad apples, bad cases, and bad barrels: Meta-analytic evidence about sources of unethical decisions at work.

Krasikova, D., Green, S. G., LeBreton, J. L. (2013). Destructive leadership: A theoretical review, integration, and future research agenda. Journal of Management, 39, 1308-1338.

Krueger, R., Eaton, N., Clark, L., Watson, D., Markon, K., Derringer, J., ...Skodol, A., (2011a). Deriving an empirical structure of personality pathology for DSM-5. Journal of Personality Disorders, 25, 170-191.

Krueger, R., Eaton, N., Derringer, J., Markon, K., Watson, D., \& Skodol, A. (2011b). Personality in the DSM-5: Helping delineate personality disorder content and framing the metastructure. Journal of Personality Assessment, 93, 325-331.

LeBreton, J. M., Barksdale, C. D., Robin, J. D., \& James, L. R. (2007). Measurement issues associated with conditional reasoning tests: Deception and faking. Journal of Applied Psychology, 92, 1-16. 
LeBreton, J. M., Binning, J. F., \& Adorno, A. J. (2006). Subclinical psychopaths. In J. C. Thomas \& D. Segal (Eds.), Comprehensive handbook of personality and psychopathology, Vol. I, Personality and everyday functioning (pp. 388-411). New York: John Wiley and Sons, Inc.

Lee, K., \& Ashton, M. (2005). Psychopathy, Machiavellianism, and narcissism in the Five-Factor Model and the HEXACO model of personality structure. Personality and Individual Differences, 38, 1571-1582.

Lee, K., Ashton, M., \& De Vries, R. (2005). Predicting workplace delinquency and integrity with the HEXACO and Five-Factor Models of personality structure. Human Performance, 18, 179-197.

Leslie, J., \& Van Velsor, E. (1996). A look at derailment today: North America and Europe. Greensboro, NC: Center for Creative Leadership.

Levashina, J., \& Campion, M. (2006). A model of faking likelihood in the employment interview. International Journal of Selection and Assessment, 14, 299-316.

Liu, D., Liao, H., Loi, R. (2012). The dark side of leadership: A three-level investigation of the cascading effect of abusive supervision on employee creativity. Academy of Management Journal, 55, 1187-1212.

Lombardo, M., \& McCauley, C. (1994). Benchmarks: A manual and trainer's guide. Greensboro, NC: Center for Creative Leadership.

Lombardo, M., Ruderman, M., \& McCauley, C. (1988). Explanations of success and derailment in upper-level management positions. Journal of Business and Psychology, 2, 199-216.

Lynam, D. R., \& Widiger, T. A. (2007). Using a general model of personality to identify the basic elements of psychopathy. Journal of Personality Disorders, 21, 160-178.

McClelland, D. (1985). Human motivation. Cambridge, England: Cambridge University Press.

McClelland, D. C., Koestner, R., \& Weinberger, J. (1989). How do self-attributed and implicit motives differ? Psychological Review, 96, 690-702.

McDonald, M. M., Donnellan, M. B., \& Navarrete, C. D. (2012). A life history approach to understanding the Dark Triad. Personality and Individual Differences, 52, 601-605.

Markon, K. E., Krueger, R. F., \& Watson, D. (2005). Delineating the structure of normal and abnormal personality: An integrative hierarchical approach. Journal of Personality and Social Psychology, 88, 139-157.

Miller, J. D., Bagby, R. M., Pilkonis, P. A., Reynolds, S. K., \& Lynam, D. R. (2005). A simplified technique for scoring DSM-IV personality disorders with the five-factor model. Assessment, 12, 404-415.

Miller, J. D., Few, L. R., Seibert, L. A., Watts, A., Zeichner, A., \& Lynam, D. R. (in press-a). An examination of the Dirty Dozen measure of psychopathy: A cautionary tale about the costs of brief measures. Psychological Assessment.

Miller, J., Gentile, B., Wilson, L., \& Campbell, W. K. (in press-b). Grandiose and vulnerable narcissism and the DSM-5 pathological personality trait model. Journal of Personality Assessment.

Morf, C. C., \& Rhodewalt, F. (2001). Unraveling the paradoxes of narcissism: A dynamic self-regulatory processing model. Psychological Inquiry, 12, 177-196.

Morgeson, F. P., Campion, M. A., Dipboye, R. L., Hollenbeck, J. R., Murphy, K., \& Schmitt, N. (2007). Are we getting fooled again? Coming to terms with limitations in the use of personality tests for personnel selection. Personnel Psychology, 60, 1029-1049.

Moscoco, S., \& Salgado, J. (2004). “Dark side” personality styles as predictors of task, contextual, and job performance. International Journal of Selection and Assessment, 12, 356-362.

Murray, H. A. (1938). Explorations in personality. New York: Oxford University Press.

O’Boyle, E. H., Forsyth, D. R., Banks, G. C., \& McDaniel, M. A. (2012). A meta-analysis of the Dark Triad and work behavior: A social exchange perspective. Journal of Applied Psychology, 97, 557-579.

Padilla, A., Hogan, R., \& Kaiser, R. B. (2007). The toxic triangle: Destructive leaders, susceptible followers, and conducive environments. The Leadership Quarterly, 18, 176-194.

Paulhus, D. L. (1998). Interpersonal and intrapsychic adaptiveness of trait self-enhancement: A mixed blessing? Journal of Personality and Social Psychology, 74, 1197-1208.

Paulhus, D., Westlake, B., Calvez, S., \& Harms, P. D. (in press) Self-presentation success: A matter of self-promotion, not self-enhancement? Journal of Applied Social Psychology.

Paulhus, D. L., \& Williams, K. (2002). The Dark Triad of personality: Narcissism, Machiavellianism, and Psychopathy. Journal of Research in Personality, 36, 556-568.

Raskin, R., \& Hall, C. S. (1979). A narcissistic personality inventory. Psychological Report, 45, 590.

Raskin, R., Novacek, J., \& Hogan, R. (1991). Narcissism, self-esteem, and defensive self-enhancement. Journal of Personality, 59, 19-38.

Resick, C., Whitman, D., Weingarden, S., \& Hiller, N. (2009). The bright-side and dark-side of CEO personality: Examining core self-evaluations, narcissism, transformational leadership, and strategic influence. Journal of Applied Psychology, 94, 1365-1381.

Roberts, B. W., Harms, P. D., Smith, J., Wood, D., \& Webb, M. (2006a). Methods in personality psychology. In Eid, M., \& Diener, E. (Eds.) Handbook of psychological assessment: A multimethod perspective: 321-325. Washington, D.C.: 
American Psychological Association.

Roberts, B. W., Walton, K., \& Veichtbauer, W. (2006b). Patterns of mean-level change in personality across the life course: A meta-analysis of longitudinal studies. Psychological Bulletin, 132, 1-25.

Rosenthal, S. A., \& Pittinsky, T. L. (2006). Narcissistic leadership. The Leadership Quarterly, 17, 617-633.

Scherer, K. T., Baysinger, M. J., Zolynsky, D., \& LeBreton, J. M. (in press). Predicting counterproductive work behaviors with sub-clinical psychopathy: Beyond the five factor model of personality. Personality and Individual Differences.

Simms, L. J., Yufik, T., \& Gros, D. F. (2010). Incremental validity of positive and negative valence in predicting personality disorder. Personality Disorders: Theory, Research, and Treatment, 1, 77-86.

Simonton, D. (1986). Presidential personality: Biographical use of the Gough Adjective Checklist. Journal of Personality and Social Psychology, 51, 149-160.

Skeem, J., Polaschek, D., Patrick, C., \& Lilienfeld, S. (2011). Psychopathic personality: Bridging the gap between scientific evidence and public policy. Psychological Science in the Public Interest, 12, 95-162.

Soyer, R., Rovenpor, J., \& Kopelman, R. (1999). Narcissism and achievement motivation as related to three facets of the sales role: Attraction, satisfaction, and performance. Journal of Business and Psychology, 14, $285-304$.

Tellegen, A. (1993). Folk concepts and psychological concepts of personality and personality disorder. Psychological Inquiry, 4, 122-130.

Thomas, C., Turkheimer, E., \& Oltmanns, T. (2003). Factorial structure of pathological personality as evaluated by peers. Journal of Abnormal Psychology, 112, 81-91.

Trull, T., \& Durrett, C. (2005). Categorical and dimensional model of personality disorder. Annual Review of Clinical Psychology, 1, 355-380.

Van Velsor, E., \& Leslie, J. B. (1995). Why executives derail: Perspectives across time and cultures. Academy of Management Executive, 9, 62-72.

Waller, N. G., \& Zavala, J. D. (1993). Evaluating the Big Five. Psychological Inquiry, 4, 131-134.

Walton, K. E., Roberts, B. W., Krueger, R. F., Blonigen, D. M., \& Hicks, B. M. (2008). Capturing abnormal personality with normal personality inventories: An item response theory approach. Journal of Personality, 76, $1623-1648$.

Weiss, H. M., \& Cropanzano, R. (1996). Affective events theory: A theoretical discussion of the structure, causes, and consequences of affective experiences at work. In B. M. Staw \& L. L. Cummings (Eds.), Research in organizational behavior (Vol. 18, pp. 1-74). Greenwich, CT: JAI Press.

Widiger, T. A., \& Trull, T. J. (2006). Personality and psychopathology: An application of the five-factor model. Journal of Personality, 60, 363-393.

Wille, B., De Fruyt, F., \& De Clerq, B. (2013). Expanding and reconceptualizing aberrant personality at work: Validity of five-factor aberrant personality tendencies to predict career outcomes. Personnel Psychology, 66, 173-223.

Wilson, T. D., \& Brekke, N. (1994). Mental contamination and mental correction: Unwanted influences on judgments and evaluations. Psychological Bulletin, 116, 117-142.

Winter, D. G., John, O. P., Stewart, A. J., Klohnen, E. C., \& Duncan, L. E. (1998). Traits and motives: Toward an integration of two traditions in personality research. Psychological Review, 105, 230-250.

Woody, E., \& Claridge, G. (1977). Psychoticism and thinking. British Journal of Social and Clinical Psychology, 16, 241-248.

Wu, J. Y. (2010). Ethical and unethical negotiation tactic usage: Considering the role of aberrant personality. Unpublished doctoral dissertation, Purdue University.

Wu, J., \& LeBreton, J. M. (2011). Reconsidering the dispositional basis of counterproductive work behavior: The role of aberrant personality traits. Personnel Psychology, 64, 593-626.

Yarkoni, T. (2010). The abbreviation of personality, or how to measure 200 personality scales with 200 items. Journal of Research in Personality, 44, 180-198.

Zaccaro, S. (2012). Individual differences and leadership: Contributions to a third tipping point. The Leadership Quarterly, 23, 718-728.

Zettler, I. \& Hilbig, B. (2010). Honesty-humility and a person-situation interaction at work. European Journal of Personality, 24, 569-582. 